\title{
The Economic Stress Model in Emerging Adulthood : The Role of Social Relationships and Financial Capability
}

\section{Ranta, Mette}

2020-12

Ranta , M , Punamäki , R-L , Chow , A \& Salmela-Aro , K 2020 , ' The Economic Stress

Model in Emerging Adulthood: The Role of Social Relationships and Financial Capability ' ,

Emerging adulthood, vol. 8 , no. 6 , 2167696819893574 , pp. 496-508 . https://doi.org/10.1177/2167696819893574

http://hdl.handle.net/10138/322105

https://doi.org/10.1177/2167696819893574

acceptedVersion

Downloaded from Helda, University of Helsinki institutional repository.

This is an electronic reprint of the original article.

This reprint may differ from the original in pagination and typographic detail.

Please cite the original version. 


\section{Emerging Adulthood}

\section{The Economic Stress Model in Emerging Adulthood: The Role of Social Relationships and Financial Capability}

\begin{tabular}{|c|l|}
\hline Journal: & Emerging Adulthood \\
\hline Manuscript ID & EA-18-0161.R4 \\
\hline Keywords: & $\begin{array}{l}\text { Financial capability, Economic stress, Social relationships, Well-being, } \\
\text { Longitudinal }\end{array}$ \\
\hline Abstract: & $\begin{array}{l}\text { Families mobilize psychosocial resources to attune negative } \\
\text { consequences of economic hardship, but research is lacking among } \\
\text { youth. We propose an Economic Stress Model among Emerging Adults } \\
\text { (ESM-EA) conceptualizing age-salient social relationships and financial } \\
\text { capability as mediators between economic hardship and well-being. The } \\
\text { ESM-EA was tested in a three-wave prospective study following the 2008 } \\
\text { economic recession, as part of the Finnish Educational Transitions } \\
\text { (FinEdu) Studies. The sample consisted of 551 emerging adults (55.5\% } \\
\text { female) who participated at ages 23, 25 and 28. Economic pressures and } \\
\text { financial capability mediated the effect of economic hardship on well- } \\
\text { being, whereas social relationships did not. Individuals with an } \\
\text { unfavorable financial situation at age 25 were more likely to show lower } \\
\text { life satisfaction and higher depressive symptoms at 28 when they } \\
\text { reported a higher level of economic pressures and a lower level of } \\
\text { financial capability. Findings emphasize emerging adults' age-salient } \\
\text { financial adjustments and management in enhancing well-being. }\end{array}$ \\
\hline
\end{tabular}

\section{SCHOLARONE Manuscripts}




\title{
THE ECONOMIC STRESS MODEL IN EMERGING ADULTHOOD
}

The Economic Stress Model in Emerging Adulthood:

The Role of Social Relationships and Financial Capability

\begin{abstract}
Families mobilize psychosocial resources to attune negative consequences of economic hardship, but research is lacking among youth. We propose an Economic Stress Model among Emerging Adults (ESM-EA) conceptualizing age-salient social relationships and financial capability as mediators between economic hardship and well-being. The ESM-EA was tested in a three-wave prospective study following the 2008 economic recession, as part of the Finnish Educational Transitions (FinEdu) Studies. The sample consisted of 551 emerging adults (55.5\% female) who participated at ages 23,25 and 28. Economic pressures and financial capability mediated the effect of economic hardship on wellbeing, whereas social relationships did not. Individuals with an unfavorable financial situation at age 25 were more likely to show lower life satisfaction and higher depressive symptoms at 28 when they reported a higher level of economic pressures and a lower level of financial capability. Findings emphasize emerging adults' age-salient financial adjustments and management in enhancing wellbeing.
\end{abstract}

Keywords: Financial capability, economic stress, social relationships, well-being, longitudinal 


\section{THE ECONOMIC STRESS MODEL IN EMERGING ADULTHOOD}

Ample evidence shows that economic stress poses a risk for mental health problems and decreases life satisfaction and psychosocial adjustment (Conger, Conger, \& Martin, 2010; Jorgensen, Jamieson, \& Martin, 2010). However, economic stress, involving economic hardship and economic pressures (Conger \& Elder, 1994), does not hamper well-being only directly, but also through their negative effects on other life domains. Research based on the Family Economic Stress Model (FESM; Conger \& Elder, 1994) has confirmed that the negative consequences of family economic hardship, induced by an economic recession or work instability, on children's and adolescents' mental health were mediated by marital conflicts and punitive parenting (Gassman-Pines, Gibson-Davis, \& Ananat, 2015; Masarik \& Conger, 2017). Following the same vein, among emerging adults, the negative effects of personal economic hardship on well-being could indirectly pass through increased economic pressures, and impaired social relationships and financial capability salient in this life phase. Social relationships and financial capability may change vigorously as individuals develop across the critical transition to financial independence during emerging adulthood (Arnett, 2004; Wood et al., 2018). These changes may be decisive for the potential impacts of economic hardship on well-being.

Subsequently, this prospective three-wave study follows emerging adults from the age of 23 to 28 years and tests a proposed Economic Stress Model in Emerging Adulthood, ESM-EA, as illustrated in Figure 1. The study examines the role of emerging adults' economic pressures, age-salient social relationships, and financial capability in mediating between own economic hardship and well-being in the context of economic upheavals in Finland, following an economic recession due to the 2008 global economic crisis. The recession caused a substantial rise in youth unemployment, reaching $23 \%$ in early 2010 (Official Statistics of Finland, 2010). However, as a Nordic welfare state with a strong public sector, Finland provides emerging adults fundamental governmental financial support, such as housing allowance, guaranteed student loan, or social welfare that possible buffer the negative impacts of economic upheavals. 


\section{THE ECONOMIC STRESS MODEL IN EMERGING ADULTHOOD}

\section{Economic Hardship and Well-Being in Emerging Adulthood}

As emerging adults strive for independence, they shift their locus of seeking security from parents to peers, romantic partners, and other adults (Arnett, 2004; Wood et al., 2018). Furthermore, formative life course transitions of emerging adulthood involve establishing new social bonds, seeking educational opportunities, and establishing a family (Buchmann \& Kriesi, 2011). These transitions demand increased financial responsibility (Arnett, 2004), and economic uncertainty can result in postponement of important developmental tasks. Research shows, for instance, that an instable income and employment insecurity may delay the transition to parenthood (Mills \& Blossfeld, 2005).

Beneficial financial conditions and employment, in turn, have been identified as the most important correlates of well-being, self-confidence, life management and sense of capability (Cunnien, MartinRogers, \& Mortimer, 2009). Therefore, the proposed ESM-EM emphasizes the importance of emerging adults' personal financial situation and proposes that their own economic hardship forms a risk for deteriorated well-being.

However, we could not find studies dealing with emerging adults' own economic hardship, while there are studies available on the role of family economic hardship on subsequent well-being. A longitudinal Swedish study (Elwér, Hammmarström, Strandh, \& Gustafsson, 2015) found that economic stress that lasted through adolescence to middle age predicted a heightened level of mental health problems, indicated by worry, anxiety, panic and depressive symptoms. The results thus confirmed that long duration and accumulation of economic stress formed mental health risks, and, among men, the timing of economic stress in adolescence was an especially significant risk factor. A prospective three-wave study in the United States found that family economic pressures, and maternal and early adolescents' depressive symptoms, predicted heightened risk for adulthood depression, mediated through harsh maternal parenting in late adolescence (Kavanaugh, Neppl, \& Melby, 2018). A Finnish register study showed that childhood economic hardship, such as parental over-indebtedness, 


\section{THE ECONOMIC STRESS MODEL IN EMERGING ADULTHOOD}

predicted clinically significant depression among emerging adults, especially women (Tanskanen, 2015).

Most available research deals with family economic hardship influencing adolescents. As economic hardship diminishes family members' mental and relational resources, adolescents seem to be especially vulnerable and show multiple developmental problems, such as aggression, lack of prosocial behavior, excessive drinking, and depression (Conger, Martin, Masarik, Widaman, \& Donnellan, 2015; De Haan, Boljevac, \& Schaefer, 2010; Ponnet, 2014; White, Liu, Nair, \& Tein, 2015). Family economic hardship can also reduce adolescents' sense of mastery, self-confidence and trust in own capabilities to influence the future (Conger, Conger, Matthews, \& Elder, 1999). In similar vein, the current study expects emerging adults' own economic hardship to tax their sense of mastery and capabilities and possibly result in decreased well-being.

\section{From Economic Hardship to Economic Pressures}

The uncertainty of macroeconomic trends and global and local recessions force individuals to struggle to make ends meet and adjust everyday life finances (Baek \& DeVaney, 2010; James, Brown, Goodsell, Stovall, \& Flaherty, 2010). Emerging adulthood is also a prime time for learning to manage own finances and adapt personal consumption habits to available financial resources (Kim et al., 2003; Shim et al., 2009). The core idea of the proposed ESM-EA model is that economic hardship (e.g., a loss of income, accumulated low income, and income insufficiency) diminishes emerging adults' psychosocial resources and generates increased economic pressures that are tangible ways to make adjustments. They involve efforts to make ends meet and practical financial cutbacks in order to adjust expenditures to the present economic situation, e.g., in decreasing housing expenses or in postponing purchases (Conger \& Elder, 1994; Conger et al., 1999). These pressures give psychological meaning to economic hardship, and thus mediate its influence on social and developmental life domains and wellbeing. 


\section{THE ECONOMIC STRESS MODEL IN EMERGING ADULTHOOD}

Research confirms that economic pressures mediate, or explain, the association between family economic hardship and adolescents' mental health problems, such as depressive symptoms (Conger, Conger, \& Martin, 2010; Donnellan, Conger, McAdams, \& Neppl, 2009; Masarik \& Conger, 2017). Yet, to our best knowledge, only one study has analyzed the types and mental health function of emerging adults' economic pressures. Stein and colleagues (2013) studied American emerging adults facing the 2008 economic crisis and found that those who reported unmet material needs and had to make numerous financial cutbacks, showed higher levels of depressive and anxiety symptoms. In Finland, a survey revealed that higher education students struggle with their financial situation, as many as $61 \%$ reporting having difficulties making ends meet (Ministry of Education and Culture, 2014). These high economic pressures are noteworthy when considering the governmental financial support to Finnish emerging adults.

\section{The Role of Social Relationships in Economic Hardship}

The proposed ESM-EA model suggests social relationships to play a crucial role in mediating the economic hardship and economic pressures on well-being. This is in line with the FESM that proposes that economic hardship and its' generated tangible pressures negatively influence family relations, e.g., by increasing couple conflicts and parenting problems (Conger et al., 1999). In emerging adulthood, salient social relationships include new friendships, work- and study-related peers, romantic relationships and newly formed own family ties (Arnett, 2004). However, we could not find studies on the role of social relationships in the link between emerging adults' own economic hardship and wellbeing. Instead, ample evidence shows direct associations between rejective social relationships and mental health problems (Noble \& McGrath, 2012), especially loneliness and depressive symptoms (Beutel et al., 2017).

In emerging adulthood, good social relationships help successful integration into society, involving a sense of belonging or a sense of community. Belonging refers to having a sense of place 


\section{THE ECONOMIC STRESS MODEL IN EMERGING ADULTHOOD}

and being part of a larger entity, from a small environment such as the family to large such as a national or global social network (Henderson, Holland, McGrellis, Sharpe, \& Thomson, 2007). Sense of community is formed through social relationships in everyday interactions and shared experiences, which create attachment between people, also known as social capital (Bourdieu, 1984; Colclough \& Sitaraman, 2005; Ellison, Steinfeld, \& Lampe, 2007). Good social relationships with peers and family and engaging in productive interaction with the work and education environment contribute to successful transitions in emerging adulthood (Salmela-Aro \& Schoon, 2009).

Two seemingly contradictory phenomena characterize today's emerging adults' social relationships. Due to globalization and fast-developing communication technology, sense of belonging in current societal conditions is no longer location-based, in other words, not limited to here and now. Yet, parallel with rapid societal change and growing economic and political uncertainties, the need for a sense of belonging and community increases among adolescents and emerging adults (Colclough \& Sitaraman, 2005). Being part of a community can offer a sense of safety in an insecure world (Bauman, 2007), and research shows that financial uncertainty enforces youth to search for "interdependence" rather than independence (Settersten, 2012).

These trends are reflected in a Finnish longitudinal study that compared adolescents' personal fears between 1983 and 2007 (Lindfors, Solantaus, \& Rimpelä, 2012). The results illustrate an urgency of seeking security within groups and gaining a sense of belonging. Fears related to loneliness, rejection in future relationships and failure to establish a family appeared in tandem with increasingly individualized societal values. Apparently, the mutual support provided by social relationships and a sense of belonging become especially important in conditions of economic recessions when governments decrease their financial support, as happened in Finland concerning family allowances and social welfare benefits in the economic recession of the 1990s (Uusitalo, 1996). Elder (1998) has introduced the concept of linked lives, illustrating how emerging adults share historical and economic 


\section{THE ECONOMIC STRESS MODEL IN EMERGING ADULTHOOD}

circumstances in relationships with significant others, which, in turn, contributes to their social belonging opportunities. As such, successful developmental transitions are bounded by social institutions and wider macro-social conditions (Salmela-Aro \& Schoon, 2009).

\section{The Role of Financial Capability in Economic Hardship}

Gaining financial independence is an important developmental task towards the transition to adulthood (Arnett, 2004). It brings increased financial responsibilities and requires competent financial life management skills (Lee \& Mortimer, 2009; Nelson \& Barry, 2005). Accordingly, the proposed ESM-EA suggests financial capability to mediate between economic hardship and well-being, in addition to economic pressures. Financial skills are important in mastering everyday life and become especially critical in unpredictable financial conditions of global economic upheavals. Emerging adults are also immersed in environments with novel and complex financial products (e.g., payday loans), digital shopping technologies, global communication, and multiple social networks (Van Campenhout, 2015).

However, research suggests that emerging adults have increasingly inadequate financial skills due to shrinking support systems and increasing individual responsibility (OECD, 2012). There is evidence, for example, about the continuous growth of young adults' over-indebtedness, also in Finland (Oksanen, Aaltonen, \& Rantala, 2016). Moreover, global economic upheavals since the 2008 economic crisis have created unfavorable prospects for emerging adults and prolonged their parental financial dependency (Lee \& Mortimer, 2009). Emerging adults are also spending longer periods in higher education while working simultaneously, which may make the transition to financial independence more complex than for previous generations (Settersten, 2012).

Managing finances in emerging adulthood requires multiple life management skills, optimal attitudes, and knowledge. The developmental model of financial capability in the transition to adulthood illustrates the multitude of the phenomenon (Serido, Shim, \& Tang, 2013). Three dimensions 


\section{THE ECONOMIC STRESS MODEL IN EMERGING ADULTHOOD}

of financial capability, financial confidence, financial well-being and financial behavior, are important for emerging adults seeking to manage social roles and financial responsibilities. Financial confidence involves perceived financial knowledge (Tokar Asaad, 2015), belief in oneself in performing financial tasks, and self-reliance in succeeding (Lee \& Mortimer, 2009; Serido et al., 2013). Financial well-being involves satisfaction with the quality of one's life management and available financial resources (Joo \& Grable, 2004), and financial behavior the practical task of everyday economy management (Serido et al., 2013).

There are some studies showing that financial difficulties in emerging adulthood challenge life management skills and deteriorate self-confidence in general (Cunnien et al., 2009), and financial confidence, in particular (Ranta \& Salmela-Aro, 2018). Ample research confirms that economic stress, difficulties in life management, and financial defaults increase the risk of general dissatisfaction and mental health problems (Gutter \& Copur, 2011; Joo \& Grable, 2004; Stein et al., 2013). A review concluded that parental financial situation remains a significant predictor of emerging adults' financial well-being and life satisfaction (Sorgente \& Lanz, 2017). Studies also suggest that parental financial socialization (Shim, Barber, Card, Xiao, \& Serido, 2010) continues to be important for emerging adults' well-being (Serido, Shim, Mishra, \& Tang, 2010). Yet, we could not detect research on the role of emerging adults' financial capability in mediating between their own economic hardship and wellbeing. Stein and group (2013) confirmed that successful financial coping strategies (e.g., seeking for additional education and sharing with others) were associated with low levels of depression and anxiety symptoms and high life satisfaction. Their study did not test whether the financial coping strategies mediated the impact of economic pressures on well-being, as the ESM-EA suggests.

\section{The Present Study}

This study tests a proposed Economic Stress Model for Emerging Adults, ESM-EA. It examines the dynamics between economic hardship and well-being in a three-wave prospective study of 


\section{THE ECONOMIC STRESS MODEL IN EMERGING ADULTHOOD}

emerging adults from 23 to 28 years of age, and suggests that economic pressures, age-salient social relationships, and financial capability function as mediators in the model. We hypothesize that economic hardship is not directly associated with well-being, but through two mediating paths. First, economic hardship predicts high economic pressures, which lead to problematic social relationships, indicated by a low level of a sense of belonging and a high level of loneliness. That subsequently associates with poor well-being, indicated by a low level of life satisfaction and a high level of depressive symptoms. Second, economic hardship predicts high economic pressures, which then predict low financial capability, indicated by low financial confidence and financial well-being, and problematic financial behavior, which subsequently is associated with poor well-being.

\section{Method}

\section{Participants and Study Procedure}

The present study is part of the longitudinal Finnish Educational Transitions (FinEdu) Studies, with three-wave follow-ups at spring 2011 (T1, age 23, $N=599$ ), autumn 2013 to spring 2014 (T2, age $25, N=610)$ and autumn 2016 to spring 2017 (T3, age 28, $N=554)$. Participants who provided an answer at a minimum of one assessment time were included in the current analysis $(N=551 ; 55.5 \%$ women and $44.5 \%$ men).

The FinEdu study began in 2004 in a medium-sized city in Finland with questionnaires addressed to all ninth-grade students in their final year of comprehensive school $(N=707)$. After the transition from comprehensive school, data collections were conducted by mail and participants filled in paper or online self-report questionnaires. The FinEdu project follows general ethical guidelines. Participants signed an informed consent and could withdraw participation at any time.

The response rates in the study were $73 \%$ of the total sample contacted $(\mathrm{N}=825)$ at $\mathrm{T} 1,72 \%$ (of $\mathrm{N}=843$ ) at $\mathrm{T} 2$, and $66 \%$ (of $\mathrm{N}=837$ ) at $\mathrm{T} 3$. The number of participants contacted varied between data collections due to available contact information and use of the social security number at T2 


\section{THE ECONOMIC STRESS MODEL IN EMERGING ADULTHOOD}

obtained from the previous data collection. Participation was motivated with a gift voucher and/or by gift certificate raffles. Numerous reminders were sent to reach satisfactory response rates. The attrition analyses showed that girls were more likely to participate in the study at $\mathrm{T} 1\left(\chi^{2}(1)=7.88, p=.005\right.$, contingency coefficient .066) and at $\mathrm{T} 2\left(\chi^{2}(1)=4.58, p=.032\right.$, contingency coefficient .051$)$. There were no significant differences regarding family socioeconomic status between participants present at $\mathrm{T} 1$ and $\mathrm{T} 2$.

\section{Measures}

Demographic factors. The demographic factors include gender, family socioeconomic status (SES), highest educational degree, and education and work situation. Data on gender and family SES are from the first FinEdu data collection in 2004, and information on education and work from T3. Family SES were assessed with the question: “What is your mother's/father's occupation?" and responses coded as (1) not in employment (students, retired or unemployed), (2) entrepreneur (selfemployed), (3) blue-collar worker, (4) lower white-collar employee, and (5) higher white-collar employee (Statistics Finland, 1989). Participants' highest educational degree at age 28 was assessed with the question: "What is the highest qualification that you have obtained so far?", answer options ranging from upper secondary school level to university level, and education and work situation with the question "What do you currently do?" with answer options covering study, work, and unemployment, and, for education additionally, "Where do you study?" with alternatives being university, polytechnic institute or other. Participants could choose more than one alternative.

Economic hardship. Economic hardship was measured with two indicators following Conger et al. (1990) and Solantaus, Leinonen and Punamäki (2004): income decrease and income insufficiency. The income decrease -score is based on participants' T1 and T2 income. They responded to the question, "How much money do you have for use monthly?", and were asked to report their available income from all sources including salary, financial support (e.g., student or housing financial 


\section{THE ECONOMIC STRESS MODEL IN EMERGING ADULTHOOD}

aid from the state), financial support from parents and relatives, loans (including mortgage/study loans, consumer credit), or other sources. The income decrease is the difference between the T1 amount from the corresponding T2. An income decrease indicated high economic hardship. Participants responded to one question about their income insufficiency: "Do you think your income covers your expenses at the moment?" with a 5-point Likert-type scale ranging from 1 (extremely well) to 5 (poorly).

Economic pressures. Economic pressures were measured with two indicators following Conger et al. (1990) and previous Finnish studies (Ranta, Punamäki, Tolvanen, \& Salmela-Aro, 2012; Solantaus et al., 2004). Inability to make ends meet was measured by a question "How much money do you have left over the day before your next paycheck or other income payment?" with a 4-point Likerttype scale ranging from 1 (not enough money to make ends meet) to 4 (more than enough money is left over to make ends meet). The scale was reverse-scored for further analysis to indicate economic pressure. Financial cutbacks were measured by a 13-item questionnaire, involving, for instance, using long-term savings for daily expenses, moving into more affordable housing, postponing large purchases, buying things on credit more than before, and taking a payday loan. Participants reported how often during the last year they had to make these financial cutbacks on a 7-point Likert-type scale ranging from 1 (not at all) to 7 (very often). These ratings were computed into a mean sum variable of financial cutbacks, with a Cronbach's alpha of .74.

Sense of belonging. Sense of belonging was conceptualized according to significant domains in emerging adulthood, i.e., societal, everyday and family (Crocetti, Prati \& Rubini, 2018; Tajfel \& Turner, 1979). The societal belonging scale included three items, Finnish society (national), Europe (international), and world citizenship (global); the everyday belonging scale included six items, friends, study and work community, social media (e.g. Facebook), organizational activities, and hobby associations (e.g., sports); and the family belonging scale included three times, childhood family, own 


\section{THE ECONOMIC STRESS MODEL IN EMERGING ADULTHOOD}

family, and relatives. Participants estimated how firmly they feel akin to these social domains on a 5point Likert-type scale ranging from 1 (not at all) to 5 (very much).

Loneliness. Loneliness was assessed by the 20-item UCLA Loneliness scale (Russell, 1996). Participants evaluated how often they have feelings such as "I miss friends", "I feel isolated", and "I feel that people are around me but not with me". They rated them on a scale from 1 (never) to 4 (often). Two items ("I am extrovert" and "I feel that I can find companionship when I want it") were omitted from further analyses due to low reliability. The loneliness scale was reverse-scored to indicate positive social relationships, and a mean sum variable was formed (Cronbach’s alpha $=.75)$.

Financial capability. The measure of financial capability is based on the conceptual model of Serido and colleagues (2013), covering financial confidence, financial well-being and financial behavior. Financial confidence was measured with the question, "How capable do you feel you are in handling financial matters?", and participants responded by a 5-point Likert-type scale ranging from 1 (not at all) to 5 (very capable). Financial well-being was measured with three items as in Shim et al. (2010): "I am satisfied with the way I pay my bills," "I have difficulty paying for things," and "I am constantly worried about money." Participants estimated how well the items describe them on a 5-point Likert-type scale ranging from 1 (strongly disagree) to 5 (strongly agree). Financial behavior was measured with five items on money-related tasks and positive financial behaviors (e.g., "I track my monthly expenses", "I spend within a budget", and "I save money monthly for the future"). Participants estimated how often they engaged in each behavior on a 5-point Likert-type scale ranging from 1 (never) to 5 (very often). The sum variables were constructed for financial well-being (Cronbach's alpha $=.74)$ and financial behavior (Cronbach’s alpha $=.70)$.

Life satisfaction. Life satisfaction was measured by the five-item Satisfaction with Life Scale (SWLS; Diener, Emmons, Larsen, \& Griffins, 1985). It covers general satisfactions, for example, "I am satisfied with my life," and "The conditions of my life are excellent". Participants estimated on a 7- 


\section{THE ECONOMIC STRESS MODEL IN EMERGING ADULTHOOD}

point Likert-type scale how well the descriptions fit them ranging from 1 (totally disagree) to 7 (totally agree). A sum score was calculated, and Cronbach's alpha was .92.

Depressive symptoms. Depressive symptoms were assessed with the 10-item Depression Scale (DEPS) (Salokangas, Stengård, \& Poutanen, 1995). The DEPS covers common depressive symptoms such as "I have felt blue" or "I have not enjoyed my life". Participants estimated how well the symptom descriptions fit their mood during the last month on a 4-point Likert-type scale ranging from 1 (not at all) to 4 (very much). A sum score was constructed with the Cronbach's alpha of .91.

\section{Analysis Strategy}

We performed Structural Equation Modeling (SEM) with latent constructs and manifest variables using three waves of data to test the ESM-EA of economic pressures, social relationships and financial capability mediating between economic hardship and well-being. The statistical software program Mplus 8 was used (Muthén \& Muthén, 1998-2017). Full information maximum likelihood method was applied for handling missing values. The significance of the indirect effects (mediations) were tested by the bootstrapping method, as Mplus generates bias-corrected confidence intervals (CIs; 95\%) with 1,000 resampled bootstrapping tests and provides significances for the indirect effects. The goodness-of-fit of the tested model was indicated by (1) a nonsignificant $\chi^{2}$-test value, (2) Comparative Fit Indexes of CFI $\geq 0.95$, (3) Tucker-Lewis Index (TLI) $\geq 0.95$, (4) Root Mean Square Error of Approximation $($ RMSEA $) \leq 0.06$, and (5) Standardized Root Mean Square Residual $(\mathrm{SRMR}) \leq 0.08$ (Hu \& Bentler, 1999).

First, we tested the measurement models of the latent constructs of the proposed ESM-EA mediation SEM model: Economic pressures (two manifest variables of Making ends meet and Financial cutbacks), Social relationships (four manifest variables of Societal belonging, Everyday belonging and Family belonging, and Loneliness), and Financial capability (three manifest variables of Financial confidence, Financial well-being and Financial behavior). Second, we specified a 


\section{THE ECONOMIC STRESS MODEL IN EMERGING ADULTHOOD}

hypothesized SEM model that simultaneously tests both direct and indirect associations between economic hardship, indicated by two manifest variables of Income decrease between 23 and 25 years of age (2011 and 2013) and Income insufficiency (2013) and two manifest variables of well-being, Life satisfaction and Depressive symptoms at 28 years. Economic hardship manifest variables were entered as exogenous variables and the endogenous latent constructs of Economic pressures at 25 years of age (2013), Social relationships and Financial capability, both at 28 years of age (2016), were regressed on the two economic hardship manifest variables. Thereafter, the Life satisfaction and Depressive symptoms manifest variables were regressed on the hypothesized latent mediating constructs of Economic Pressures, Social Relationships and Financial capability. The residuals between the exogenous variables (Income decrease and Income insufficiency) were allowed to covariate, as well as between the outcome variables (Life satisfaction and Depressive symptoms) in order to reflect shared sources of variance not included in the model.

\section{Results}

\section{Descriptive Statistics}

The sample characteristics including gender, family socioeconomic status (SES), highest educational degree and education and work situation at age 28 are presented as supplemental online material. Concerning SES, a third of fathers were higher white-collar employees such as managers, and about half of mothers were lower white-collar employees such as administrative or sales workers. At age 28 , half of the participants had gained a polytechnic or university degree, while almost a half had a high school or vocational school degree. About two thirds of participants were working.

Table 1 shows the correlations between study variables and their means and standard deviations. Results show that indicators of economic hardship (income decrease and income insufficiency) significantly correlated with indicators of economic pressures. Indicators of economic 


\section{THE ECONOMIC STRESS MODEL IN EMERGING ADULTHOOD}

hardship correlated negatively with behavioral and well-being aspects of financial capability. Finally, economic hardship, economic pressures, sense of belonging and financial capability all correlated significantly with life satisfaction and depressive symptoms, indicating well-being.

\section{Testing the Economic Stress Model of Emerging Adults}

The SEM measurement models of the latent constructs of economic pressures, social relationships and financial capability are shown as supplemental online material. The results of the Confirmatory Factor Analysis (CFA) showed good fit indices of the model (CFI = .95; TLI = .92; RMSEA $=.07$ [90\% CI: .051-.082], and SRMR $=.04)$. Yet, the $\chi^{2}$-value was significant $\left(\chi^{2}=81.08\right.$ $(\mathrm{df}=24, p<.001)$, as is often the case in large samples (Hu \& Bentler, 1999). All manifest variables loaded significantly on corresponding latent constructs, standardized parameter estimate values being more than .55 , except loneliness on social relationships $(\beta=.35)$.

Figure 2 illustrates the significant direct paths of the hypothesized ESM-EA model and Table 2 shows the significant indirect associations of the model. The SEM testing simultaneously direct and indirect (mediating) paths between economic hardship and well-being showed adequate goodness-of-fit for $\mathrm{CFI}=.94 ; \mathrm{TLI}=.91 ; \mathrm{RMSEA}=.07$ [90\% CI: .057-.082], SRMR $=.045$, although the $\chi^{2}$-value was significant $\left(\chi^{2}=152.03, \mathrm{df}=52, p<.001\right)$

The hypotheses were substantiated for economic pressures and financial capability mediating between economic hardship and well-being, but not for social relationships. As hypothesized, economic hardship, indicated by manifest variables of income decrease $(\beta=.16, t=-3.68, p<.001)$, and income insufficiency $(\beta=.72, t=-19.94, p<.001)$, were significantly associated with high level of economic pressures, which were further associated with low financial capability $(\beta=-.42, t=-7.85, p<$ .001). Financial capability, in turn, associated with high level of well-being, indicated by high life satisfaction $(\beta=.17, t=2.80, p<.01)$ and low depressive symptoms $(\beta=-.18, t=-3.08, p<.01)$. Yet, 


\section{THE ECONOMIC STRESS MODEL IN EMERGING ADULTHOOD}

the bootstrapped standardized indirect effects confirmed these hypothesized mediations only for income insufficiency but not for income decrease (between 23 and 25 years of age). A high income insufficiency at 25 years old predicted a lower level of life satisfaction at 28 years old, mediated through high economic pressures and low financial capability $(\beta=.05, t=2.06, p<.05,95 \% \mathrm{CI}$ : 0.02 ; 0.13). Similarly, a high income insufficiency at 25 years old predicted a higher level of depressive symptoms at 28 years of age, mediated through economic pressures and financial capability $(\beta=-.05, t$ $=2.17, p<.05,95 \% \mathrm{CI}:-0.057 ;-0.011)$. In other words, if emerging adults' insufficient income at 25 years lead to a higher level of economic pressures and to a lower level of financial capability, then they were more likely to show lower life satisfaction and higher depressive symptoms at age 28 .

Against our hypothesis, the quality of social relationships did not mediate between emerging adults' economic hardship and well-being, although a direct association was found between optimal social relationships, involving a high level of sense of belonging and low level of loneliness, and high life satisfaction $(\beta=.65, t=13.81, p<.001)$ and low depressive symptoms $(\beta=-.72, t=-17.30, p<$ $.001)$.

\section{Discussion}

The Economic Stress Model in Emerging Adulthood (ESM-EA) was constructed to depict the age-salient mediators between economic hardship and well-being among emerging adults on the verge of gaining financial independence. First, economic hardship was hypothesized to predict high levels of economic pressures, which lead to problematic social relationships and, in turn, to a poor level of wellbeing. Second, economic hardship induced economic pressures were assumed to predict low financial capability, with subsequently negative impacts on well-being. The ESM-EA is based on the Family Economic Stress Model (Conger \& Elder, 1994), but the hypothesized mediated paths reflect social and individual domains that are relevant in this developmental period: sense of belonging and financial 


\section{THE ECONOMIC STRESS MODEL IN EMERGING ADULTHOOD}

capability. The ESM-EA was tested in a three-wave prospective study of Finnish emerging adults in the aftermath of the 2008 economic crisis and the long-lasting recession of the national economy. As hypothesized, economic pressures and financial capability mediated the association between economic hardship at age 25 and well-being at age 28 . Yet, against the hypothesis, social relationships turned out not to be a significant mediator in the link between finances and well-being among emerging adults. Economic pressures also mediated between economic hardship and depressive symptoms on its own, without financial capability.

The proposed ESM-EA contributes to the call for "elaboration and extension" of research on economic stress (Conger et al., 2010, p. 699) by testing the impact of emerging adults' own economic hardship on social relationships and financial capability, and potentially on well-being. Ample evidence, based on the FESM, shows how family economic hardship can induce negative changes in family climate and parent-adolescent relationships (Masarik \& Conger, 2017). In response, this study extended the FESM to emerging adulthood, conceptualizing its multi-faceted developmental contexts.

Problematic social relationships did not mediate the negative impacts of economic hardship and economic pressures on well-being among emerging adults. In emerging adulthood, peer relations and romantic partnership partly replace the family as a source of support (Arnett, 2004; Wood et al., 2018). Our conceptualization of social relationships as a sense of belonging to various social domains or experiences of loneliness reflected that extension "from home to the world". It is thus perhaps surprising that emerging adults' own economics, either hardship or pressures, did not have an impact on that important developmental domain in the transition to adulthood. Research among early adolescents shows that family poverty and economic hardship can relate to some extent to bullying, exclusion, and loneliness (Côté-Lussier, Barnett, Kestens, Tu, \& Séguin, 2015; Tippett \& Wolke, 2014), perhaps reflecting societal values of highly cherished economic prosperity or lack of resources for social participation, e.g., hobbies (Hjalmarsson \& Mood, 2016). The nature of social relationships 


\section{THE ECONOMIC STRESS MODEL IN EMERGING ADULTHOOD}

may be different in emerging adulthood, as social pressure for unity is not as strong as in early adolescence. Therefore, economic success may not determine the quality of emerging adults' social relations, and, here, economic pressures such as cutting expenditures did not negatively influence their belonging or increase their loneliness.

We would need more nuanced knowledge about the paths enhancing social belonging or preventing loneliness in emerging adulthood which is a prime time for creating an own social environment. It is plausible that a part of the participating emerging adults with high economic hardship and pressures at ages 23 and 25 had made extra efforts to enhance their social belonging, while others could have withdrawn socially. Our linear-regression based SEM cannot reveal these potential opposite dynamics. Seeking social support and belonging are effective coping strategies for economic hardship, and these extra efforts indicate resilience — a phenomenon that hardships can empower individuals and add to their capacity to further handle stress and hardships (Masten \& Wright, 2010; Ungern, 2013). Consequently, the calibration of ESM-EA should detect both positive and adaptive as well as negative and isolating trajectories initiated by emerging adults' own economic hardship.

Considering the direct links in the ESM-EA, optimal social relationships, indicated by a high level of sense of belonging and a low level of loneliness, were associated with a high level of life satisfaction and a low level of depressive symptoms. The finding concurs with studies showing high mental health risks among youth isolated from work and education (Goldman-Mellor et al., 2016; Henderson, Hawke, Chaim, \& National Youth Screening Project Network, 2017), and with studies showing a protective role of optimal social relations across life-span development, including emerging adulthood (Noble \& McGrath, 2012; Salmela-Aro \& Schoon, 2009).

Economic hardship means concrete and symbolic insecurity, often accompanied with disturbed future prospects and distrust in own competences (Shek, 2003). Our findings emphasized the 


\section{THE ECONOMIC STRESS MODEL IN EMERGING ADULTHOOD}

importance of financial capability in explaining the impact of economic hardship on emerging adults' well-being. As hypothesized, emerging adults' financial confidence, financial well-being and financial behavior, conceptualized as financial capability, explained, together with economic pressure, the impact of economic hardship on well-being. These results imply that in addition to financial circumstances, the ways of coping, attitudes, subjective perceptions, and meanings of financial issues are especially crucial for emerging adults' well-being (Ranta \& Salmela-Aro, 2017; Stein et al., 2013).

The findings concur with observations of behavioral economics on the link between national gross domestic product and subjective well-being (Easterlin, McVey, Switek, Sawangfa, \& Zweig, 2010) that "money alone does not make you happy". The associations between emerging adults' economic hardship at 23-25 years of age did not directly predict their life satisfaction or depressive symptoms at age 28 . The pressures caused by the hardship and emerging adults' own capability to deal with financial matters were more essential for their well-being, maybe even for happiness. Each developmental stage has its own salient developmental tasks, and in emerging adulthood, experiences of life management, the ability to have an impact, and success in important life domains, contribute to optimistic future prospects and empowerment (Nurmi, 1993). Our study evidenced the important role of financial capability in mediating between economic hardship, economic pressures and well-being, thus providing empirical ideas of ingredients of successful transitions to adulthood. Our findings concur with others emphasizing the decisive role of independent financial responsibilities associating with good psychosocial adjustment (Settersten, 2012). In line with FESM, the ways how emerging adults adjust their finances to make ends meet turned out to be important in mediating between economic hardships and well-being. In other words, although objective, concrete monetary monthly income is important, the ways how individuals reflect upon it, estimate its adequacy for personal consumption, and make adjustments are highly relevant for feelings of mastery and capability, and ultimately to well-being. 


\section{THE ECONOMIC STRESS MODEL IN EMERGING ADULTHOOD}

This study corresponds to the call for research on youth financial capability in diverse societal contexts (Serido et al., 2013). The results suggest that also in relatively wealthy countries, emerging adults are vulnerable to economic turbulence and macroeconomic upheavals. This study shows that income insecurity and loss, together with experiences of economic pressures, can challenge selfsufficiency attainment with financial independence. The ability to make ends meet and comprehensive financial capability are important markers of adulthood, and their successful attainment in emerging adulthood can significantly contribute to well-being and feelings of security (Stein et al., 2013; UNICEF Office of Research, 2014).

The findings of the ESM-EA model can be applied when tailoring promotion, prevention or intervention programs for emerging adults in the field of financial management. Financial capability, especially, is a highly malleable phenomenon, and attitude change, interest in financial management and an increased sense of competence are viable elements in these specific programs. Previous literature provides some examples of intervention programs, showing promising results of promoting agency, self-confidence and expertise in financial matters, instead of giving merely economic assistance (Mbae, 2016; Naong, 2011).

The present study has the following main limitations, alongside its contributions. First, the results cannot be generalized to all emerging adults, nationally or internationally, without precaution. We did not test the ESM-EA model separately for women and men, which should be the task for further model development. In traditional societies, men are considered more responsible for family finances (Buchmann, 1989), and it would be interesting to analyze this developmental model in societies differing in their gender-equality. Second, only emerging adults living in one city were given the chance to participate in the longitudinal study. Third, the Finnish context must be considered, as youth are granted extensive public financial support to buffer negative impacts of economic hardships. It would thus be fruitful to replicate the ESM-EA in societies without comprehensive governmental 


\section{THE ECONOMIC STRESS MODEL IN EMERGING ADULTHOOD}

social security systems, as well as free education including university studies. Fourth, our SEM model included both manifest variables and latent constructs, as modelling of economic hardship and wellbeing as latent constructs did not fit the data. Finally, the ESM-EA model does not take into account recursive associations. It is plausible that, for instance, financial capability influences the economic pressures and not only vice versa, as we tested. Depressive symptoms can also deteriorate social relationships, and not only vice versa. The model should thus be replicated and calibrated in further studies.

In conclusion, the present study contributes to previous research by studying economic hardship possibly predicting emerging adults' well-being. Importantly, the model described emerging adults struggling with their own economic hardship, but also added developmentally novel information to understand the resources and deficits of the economic life domains in this important transition period. Our findings illustrate the complexity of the link between emerging adults' financial situation and wellbeing. The multi-dimensional constructs, including income decrease and income insufficiency, and attitudinal and behavioral financial capabilities, are important in understanding the demands for independent personal economics of emerging adults.

\section{References}

Arnett, J. J. (2004). Emerging adulthood. The winding road from the late teens through the twenties. New York: Oxford University Press.

Baek, E., \& DeVaney, S. A. (2010). How do families manage their economic hardship? Family Relations, 59, 358-368. doi:10.1111/j.1741-3729.2010.00608.x

Bauman, Z. (2007). Liquid times. Living in age of uncertainty. Cambridge: Polity. Beutel, M. E., Klein, E. M., Brähler, E., Reiner, I., Jünger, C., Michal, M., ... Tibubos, A.N. (2017). Loneliness in the general population: prevalence, determinants and relations to mental health. BMC Psychiatry, 17(1), 97. doi: 10.1186/s12888-017-1262-x 


\section{THE ECONOMIC STRESS MODEL IN EMERGING ADULTHOOD}

Bourdieu, P. (1984). Distinction: A social critique of the judgement of taste. Harvard:

Harvard University Press.

Buchmann, M. (1989). The Script of Life in Modern Society: Entry into Adulthood in a Changing World. Chicago: University of Chicago Press.

Buchmann, M. \& Kriesi, I. (2011). Transition to Adulthood in Europe. Annual Review of Sociology, 37, 481-503. doi:10.1146/annurev-soc-081309-150212

Van Campenhout, G. (2015). Revaluing the role of parents as financial socialization agents in youth financial literacy programs. Journal of Consumer Affairs, 49(1), 186-222.

Colclough, G. \& Sitaraman, B. (2005). Community and social capital: What is the difference? Sociological Inquiry, 75, 474-496. doi:10.1111/j.1475-682X.2005.00133.x

Conger, R. D., Elder, G. H. J., Lorenz, F. O., Conger, K. J., Simons, R. L., Whitbeck, L. B., et al. (1990). Linking economic hardship to marital quality and instability. Journal of Marriage and Family, 52, 643-656.

Conger, R. D., Conger, K. J., Martin, M. J. (2010). Socioeconomic status, family processes, and individual development. Journal of Marriage and Family, 72, 685-704. doi:10.1111/j.17413737.2010.00725.x

Conger, R. D., Conger, K. J., Matthews, L. S. \& Elder, G. H., Jr. (1999). Pathways to economic influence on adolescent adjustment. American Journal of Community Psychology, 27(4), 519541.

Conger, R. D. \& Elder, G. H. J. (1994). Families in troubled times: Adapting to change in rural America (1st Ed.). New York: Aldine De Gruyter.

Conger, R. D., Martin, M. J., Masarik, A. S., Widaman, K. F., \& Donnellan, M. B. (2015). Social and economic antecedents and consequences of adolescent aggressive personality: Predictions from 


\section{THE ECONOMIC STRESS MODEL IN EMERGING ADULTHOOD}

the interactionist model. Development and Psychopatholy, 27(4), 1111-1127. doi:10.1017/S0954579415000711

Côté-Lussier, C., Barnett, T. A., Kestens, Y., Tu, M. T., \& Séguin, L. (2015). The role of the residential neighborhood in linking youths' family poverty trajectory to decreased feelings of safety at school. Journal of Youth and Adolescence, 44(6), 1194-1207. doi:10.1007/s10964-014-0214-8

Crocetti, E., Prati, F., \& Rubini, M. (2018). The interplay of personal and social identity. European Psychologist, 23, 300-310. doi:10.1027/ 1016-9040/a000336

Cunnien, K. A., MartinRogers, N., \& Mortimer, J. T. (2009). Adolescent work experience and selfefficacy. International Journal of Sociology and Social Policy, 29(3/4), 164-175. doi:

\section{$10.1108 / 01443330910947534$}

Diener, E., Emmons, R. A., Larsen, R. J., \& Griffin, S. (1985). The Satisfaction with Life Scale. Journal of Personality Assessment, 49, 71-75. doi:10.1207/s15327752jpa4901 13

Donnellan, M. B., Conger, K. J., McAdams, K. K., \& Neppl, T. K. (2009). Personal characteristics and resilience to economic hardship and its consequences: conceptual issues and empirical illustrations. Journal of Personality, 77(6), 1645-1676. doi:10.1111/j.1467-6494.2009.00596.x

Easterlin, R. A., McVey, L. A., Switek, M., Sawangfa, O., \& Zweig, J. S. (2010). The happinessincome paradox revisited. Proceedings of the National Academy of Sciences, USA, 107, 2246322468. doi:10.1073/pnas.1015962107

Elder, G. H., Jr. (1998). The life course and human development. In W. Damon \& R. Lerner, R. (Eds.), Theoretical models of human development. Handbook of child psychology, Vol. 1. (pp. 939-991). Hoboken, NJ: John Wiley \& Sons, Inc. doi:10.1002/9780470147658.chpsy0112

Ellison, N.B., Steinfield, C., \& Lampe. C. (2007). The benefits of Facebook “friends"': Social capital and college students' use of online social network sites. Journal of Computer-Mediated Communication, 12, 1143-1168. 


\section{THE ECONOMIC STRESS MODEL IN EMERGING ADULTHOOD}

Elwér, S., Hammarström, A., Strandh, M., \& Gustafsson, P. E. (2015). Life course models of economic stress and poor mental health in mid-adulthood: Results from the prospective Northern Swedish Cohort. Scandinavian Journal of Public Health, 43, 833-840. doi:10.1177/1403494815583420

Gassman-Pines, A., Gibson-Davis, C. M., \& Ananat, E. O. (2015). How economic downturns affect children's development: An interdisciplinary perspective on pathways of influence. Child Development Perspectives, 9(4), 233-238. doi:10.1111/cdep.12137/abstract

Goldman-Mellor, S., Caspi, A., Arseneault, L., Ajala, N., Ambler, A., Danese, A., Fisher, H., Hucker, A., Odgers, C., Williams, T., Wong, C., Moffitt, T. E. (2016). Committed to work but vulnerable: self-perceptions and mental health in NEET 18-year olds from a contemporary British cohort. The Journal of Child Psychiatry \& Psychology, 57(2), 196-203. doi:10.1111/jcpp.12459

Gutter, M., \& Copur, Z. (2011). Financial behaviors and financial well-being in college students: Evidence from a national survey. Journal of Family and Economic Issues, 32, 699-714.

De Haan, L., Boljevac, T., \& Schaefer, K. (2010). Rural community characteristics, economic hardship, and peer and parental influences in early adolescent alcohol use. The Journal of Early Adolescence, 30(5), 629-650. doi: $10.1177 / 0272431609341045$

Henderson, S., Holland, J., McGrellis, S., Sharpe, S., \& Thomson, R. (2007). Inventing adulthoods. A biographical approach to youth transitions. SAGE Publications.

Henderson, J. L., Hawke, L. D., Chaim, G., \& National Youth Screening Project Network (2017). Not in employment, education or training: Mental health, substance use, and disengagement in a multi-sectoral sample of service-seeking Canadian youth. Child and Youth Services Review, 75, 138-145. doi:10.1186/s13033-017-0128-4

Hjalmarsson, S., \& Mood, C. (2015) Do poorer youth have fewer friends? The role of household and child economic resources in adolescent school-class friendships. Children and Youth Services Review, 57, 201-211. doi:10.1016/j.childyouth.2015.08.013 


\section{THE ECONOMIC STRESS MODEL IN EMERGING ADULTHOOD}

Hu, L., \& Bentler, P.M. (1999). Cutoff criteria for fit indexes in covariance structure analysis:

Conventional criteria versus new alternatives. Structural Equation Modeling, 6, 1-55.

James, S., Brown, R. B., Goodsell, T. L., Stovall, J. \& Flaherty, J. (2010). Adapting to hard times:

Family participation patterns in local thrift economies. Family Relations 59, 383-395.

$\underline{\text { doi:10.1111/j.1741-3729.2010.00610.x }}$

Joo, H., \& Grable, J. E. (2004). An exploratory framework of the determinants of financial satisfaction. Journal of Family and Economic Issues, 25, 25-50.

Jorgensen, B. S., Jamieson, R. D., \& Martin, J. F. (2010). Income, sense of community and subjective well-being: Combining economic and psychological variables. Journal of Economic Psychology 31(4), 612-623. doi:10.1016/j.joep.2010.04.002

Kavanaugh, S. A., Neppl, T. K., \& Melby, J.N. (2018). Economic pressure and depressive symptoms: Testing the family stress model from adolescence to adulthood. Journal of Family Psychology 32(5), 553-698. doi:10.1037/fam0000462

Kim, J., Garman, E. T., \& Sorhaindo, B. (2003). Relationships among credit counseling clients’ financial well-being, financial behaviors, financial stressor events, and health. Financial Counseling and Planning, 14, 75-87.

Lee, J. C., Mortimer, J. T. (2009). Family socialization, economic self-efficacy, and the attainment of financial independence in early adulthood. Longitudinal and Life Course Studies 1(1), 45-62.

Lindfors, P., Solantaus, T., \& Rimpelä, A. (2012). Fears for the future among Finnish adolescents in 1983-2007: From global concerns to ill health and loneliness. Journal of Adolescence, 35, 991999. doi:10.1016/j.adolescence.2012.02.003

Masarik, A. S., \& Conger, R. D. (2017). Stress and child development: A review of the Family Stress Model. Current Opinion in Psychology, 13, 85-90. doi:10.1016/j.copsyc. 2016.05.008 


\section{THE ECONOMIC STRESS MODEL IN EMERGING ADULTHOOD}

Masten, A. S., \& Wright, M. (2010). Resilience over the lifespan. Developmental perspectives on resistance, recovery, and transformation. In J. W. Reich, A. J. Zautra, \& J. S. Hall (Eds.), Handbook of adult resilience (pp. 213-237). New York: Guilford.

Mbae, F. N., Mukulu, E., \& Kihoro, J. M. (2016). Critical literature review on how individual socioeconomic empowerment occurs in youth groups. International Journal of Academic Research in Accounting, Finance and Management Sciences, 6(3), 119-130.

Mills, M., \& Blossfield, H. P. (2005). Globalization, uncertainty and the early life course. A theoretical framework. In H.-P. Blossfield, E. Klijzing, M. Mills \& K. Kurz (Eds.), Globalization, uncertainty and youth in society (pp. 1-24). London/New York: Routledge.

Ministry of Education and Culture (2014). Student survey 2014. Higher education students' income and studies. Helsinki: Ministry of Education and Culture, 10.

Muthén \& Muthén (1998-2017). Mplus user's guide, and Mplus version 6.0.

Naong, M. N. (2011). Promotion of entrepreneurship education - A remedy to graduates and youth unemployment - A theoretical perspective. Journal of Social Sciences, 28(3), 181-189.

Nelson, L. B., \& Barry, C. M. (2005). Distinguishing features of emerging adulthood: The role of selfclassification as an adult. Journal of Adolescent Research, 20, 242-262.

Noble T., \& McGrath H. (2012) Wellbeing and resilience in young people and the role of positive relationships. In S. Roffey (Ed.), Positive relationships (pp. 17-33). Dordrecht: Springer.

Nurmi, J.-E. (1993). Adolescent development in an age-graded context: The role of personal beliefs, goals, and strategies in the tackling of developmental tasks and standards. International Journal of Behavioral Development, 16, 169-189.

OECD. (2012). PISA 2012 financial literacy assessment framework. Retrieved from http://www.oecd.org/pisa/pisaproducts/46962580.pdf 


\section{THE ECONOMIC STRESS MODEL IN EMERGING ADULTHOOD}

Oksanen, A., Aaltonen, M., \& Rantala, K. (2016) Debt problems and life transitions: A register-based panel study of Finnish young people. Journal of Youth Studies, 19(9), 1184-1203 doi:

\section{$\underline{10.1080 / 13676261.2016 .1145638}$}

Ponnet, K. (2014). Financial stress, parent functioning and adolescent problem behavior: an actorpartner interdependence approach to family stress processes in low-, middle-, and high-income families. Journal of Youth \& Adolescence, 43(10), 1752-1769. doi:10.1007/ s10964- 014-0159-y

Ranta, M., \& Salmela-Aro, K. (2018). Subjective financial situation and financial capability of young adults in Finland. International Journal of Behavioral Development, 42(6) 525-534. doi:10.1177/0165025417745382

Russell, D. (1996). UCLA Loneliness Scale (Version 3): Reliability, validity, and factor structure. Journal of Personality Assessment, 66, 20-40. doi:10.1207/s15327752jpa6601_2

Salmela-Aro, K., \& Schoon I. (2009) Youth development in Europe. Transitions and identities. European Psychologist, 14(4), 372-375.doi:10.1027 /1016-9040.14.4.372

Salokangas, R. K., Poutanen, O., \& Stengård, E. (1995). Screening for depression in primary care Development and validation of the Depression Scale, a screening instrument for depression. Acta Psychiatrica Scandinavica, 92(1), 10-16. https://doi.org/10.1111/j.1600-0447.1995.tb09536.x

Serido, J., Shim, S., Mishra, A., \& Tang, C. (2010). Financial parenting, financial coping behaviors, and well-being of emerging adults. Family Relations, 59(4), 453-464. http://dx.doi.org/ $\underline{10.1111 / \mathrm{j} .1741-3729.2010 .00615 . \mathrm{x}}$

Serido, J., Shim, S., \& Tang, C. (2013). A developmental model of financial capability: A framework for promoting a successful transition to adulthood. International Journal of Behavioral Development, 37, 287-297. doi:10.1177/0165025413479476

Settersten, R. A., Jr. (2012). The contemporary context of young adulthood in the USA: From demography to development, from private troubles to public issues. In A. Booth, S. L. Brown, N. 


\section{THE ECONOMIC STRESS MODEL IN EMERGING ADULTHOOD}

S. Landale, W. D. Manning, \& S. M. McHale (Eds.), Early adulthood in a family context (pp. 326). New York: Springer. doi:10. 1007/978-1-4614-1436-0 1

Shek, D. T. L. (2003). Economic stress, psychological well-being and problem behavior in Chinese adolescents with economic disadvantage. Journal of Youth and Adolescence, 32(4), 259-266.

Shim, S., Barber, B. L., Card, N. A., Xiao, J. J., \& Serido, J. (2010). Financial socialization of first-year college students: The roles of parents, work, and education. Journal of Youth and Adolescence, 39(12), 1457-1470.

Shim, S., Xiao, J. J., Barber, B., \& Lyons, A. (2009). Pathways to life success: A conceptual model of financial well-being for young adults. Journal of Applied Developmental Psychology, 30, 708723. doi:10.1016/j.appdev.2009.02.003

Solantaus, T., Leinonen, J., \& Punamäki, R.-L. (2004). Children's mental health in times of economic recession: Replication and extension of the family economic stress model in Finland. Developmental Psychology, 40(3), 412-429.

Sorgente, A., \& Lanz, M. (2017) Emerging adults' financial well-being: A scoping review. Adolescent Research Review, 2, 255-292. doi:10.1007/s40894-016-0052-x

Statistics Finland. (1989). Sosioekonomisen aseman luokitus [Classification of Socioeconomic Status]. Käsikirjoja 17 [Handbooks 17].

Stein, C. H. Hoffmann, E., Bonar, E. E., Leith, J. E., Abraham, K. M., Hamill, A. C., ... \& Fogo, W. R (2013). The United State economic crisis: Young adults' reports of economic pressures, financial and religious coping and psychological well-being. Journal of Family Economic Issues, 34, 200210. doi: $10.1007 / \mathrm{s} 10834-012-9328-\mathrm{x}$

Tajfel, H., \& Turner, J. C. (1979). An integrative theory of intergroup conflict. In W. G. Austin \& S. Worchel (Eds.), The social psychology of intergroup relations (pp. 33-47). Monterey, CA: Brooks/Cole. 


\section{THE ECONOMIC STRESS MODEL IN EMERGING ADULTHOOD}

Tanskanen, J. (2015). Parental over-indebtedness as a predictor for children's psychiatric morbidity. A 13 year follow-up of the 1987 birth cohort (Master's thesis). University of Helsinki, Finland.

Tokar Asaad, C. (2015). Financial literacy and financial behavior: Assessing knowledge and confidence. Financial Services Review, 24(2), 101-117.

Tippett, N. \& Wolke, D. (2014). Socioeconomic status and bullying: A meta-analysis. American Journal of Public Health, 104, 48-59. doi:10.2105/AJPH.2014.301960

Ungar, M. (2013). Resilience, trauma, context, and culture. Trauma, Violence, \& Abuse, 14(3), 255266. doi:10.1177/1524838013487805

Uusitalo, H. (1996). Economic crisis and social policy in Finland in the 1990s. SPRC Discussion Paper No. 70. Retrieved from https://www.sprc.unsw.edu.au/media/SPRCFile/dp070.pdf

White, R. M., Liu, Y., Nair, R. L., \& Tein, J. Y. (2015). Longitudinal and integrative tests of family stress model effects on Mexican origin adolescents. Developmental Psychology, 51(5), 649_ 662. doi:10.1037/a0038993

Wood, D., Crapnell, T., Lau, L., Bennett, A., Lotstein, D., Ferris, M., \& Kuo, A. (2018). Emerging adulthood as a critical stage in the life course. In N. Halfon, C. B. Forrest, R. M. Lerner, \& E. M. Faustman (Eds.), Handbook of life course health development (pp. 123-143). Cham: Springer. doi:10.1007/978-3-319-47143-3_7 
Table 1. Pearson's Product Moment Correlations between Economic Hardship, Economic Pressures, Social Relationships, Financial Capability and Well-Being.

\begin{tabular}{|c|c|c|c|c|c|c|c|c|c|c|c|c|c|}
\hline & \multicolumn{2}{|c|}{$\begin{array}{l}\text { Economic } \\
\text { hardship }\end{array}$} & \multicolumn{2}{|c|}{$\begin{array}{l}\text { Economic } \\
\text { pressures }\end{array}$} & \multicolumn{4}{|c|}{ Social relationships } & \multicolumn{3}{|c|}{ Financial capability } & \multicolumn{2}{|c|}{ Well-being } \\
\hline & 1 & 2 & 3 & 4 & 5 & 6 & 7 & 8 & 9 & 10 & 11 & 12 & 13 \\
\hline $\begin{array}{l}\text { Economic } \\
\text { hardship }\end{array}$ & & & & & & & & & & & & & \\
\hline $\begin{array}{l}1 \text { Income } \\
\text { decrease T1- } \\
\text { T2 }\end{array}$ & 1 & & & & & & & & & & & & \\
\hline $\begin{array}{l}2 \text { Income } \\
\text { insufficiency } \\
\text { T2 }\end{array}$ & $37 * *$ & 1 & & & & & & & & & & & \\
\hline $\begin{array}{l}\text { Economic } \\
\text { pressures }\end{array}$ & & & & & & & & & & & & & \\
\hline $\begin{array}{l}3 \text { Making } \\
\text { ends meet }\end{array}$ & $.39 * *$ & $.67 * *$ & 1 & & & & & & & & & & \\
\hline $\begin{array}{l}4 \text { Cutbacks } \\
\text { in expenses }\end{array}$ & $.26 * *$ & $.56 * *$ & $.60 * *$ & 1 & & & & & & & & & \\
\hline \multicolumn{14}{|c|}{ Social relationships } \\
\hline $\begin{array}{l}5 \text { Belonging } \\
\text { - Societal }\end{array}$ & .01 & .01 & .08 & .07 & 1 & & & & & & & & \\
\hline $\begin{array}{l}6 \text { Belonging- } \\
\text { Everyday }\end{array}$ & .01 & .00 & .03 & -.01 & $.46^{* *}$ & 1 & & & & & & & \\
\hline $\begin{array}{l}7 \text { Belonging- } \\
\text { Family }\end{array}$ & -.07 & -.04 & .01 & $-.12 *$ & $.29 * *$ & $.40 * *$ & 1 & & & & & & \\
\hline 8 Loneliness & .04 & .04 & .03 & -.03 & $.18 * *$ & $.22 * *$ & $.26^{* *}$ & 1 & & & & & \\
\hline Financial cap & ility & & & & & & & & & & & & \\
\hline
\end{tabular}




\begin{tabular}{|c|c|c|c|c|c|c|c|c|c|c|c|c|c|}
\hline 9 Confidence & -.08 & $-.17 * *$ & $-.22 * *$ & $-.22 * *$ & .08 & $.09 *$ & $16 * *$ & -.06 & 1 & & & & \\
\hline 10 Behavior & $-.13 *$ & $-.21 * *$ & $-.30 * *$ & $-.21 * *$ & $.14 * *$ & $.19 * *$ & $.14 * *$ & -.08 & $.55 * *$ & 1 & & & \\
\hline $\begin{array}{l}11 \text { Well- } \\
\text { being }\end{array}$ & $-.17 * *$ & $-.30 * *$ & $-.33 * *$ & $-.39 * *$ & $.10^{*}$ & .07 & $.14 * *$ & -.07 & $.60 * *$ & $.54 * *$ & 1 & & \\
\hline \multicolumn{14}{|l|}{ Well-being } \\
\hline $\begin{array}{l}12 \text { Life } \\
\text { satisfaction }\end{array}$ & $-.15 * *$ & $-.18 * *$ & $-.15 * *$ & $-.21 * *$ & $.30 * *$ & $.35 * *$ & $.47 * *$ & $.33 * *$ & $.30 * *$ & $.33 * *$ & $.35 * *$ & 1 & \\
\hline $\begin{array}{l}13 \\
\text { Depressive } \\
\text { symptoms }\end{array}$ & $.15^{* *}$ & $.16^{* *}$ & $.17 * *$ & $.25 * *$ & $-.28 * *$ & $-.32 * *$ & $-.38 * *$ & $-.47 * *$ & $-.32 * *$ & $-.32 * *$ & $-.41 * *$ & $-.64 * *$ & 1 \\
\hline Scale & - & $1-5$ & $1-4$ & $1-7$ & $1-5$ & $1-5$ & $1-5$ & $1-4$ & $1-5$ & $1-5$ & $1-5$ & $1-7$ & $1-4$ \\
\hline Mean & 665,98 & 2.80 & 2.60 & 2.36 & 3.28 & 2.71 & 3.39 & 2.82 & 4.14 & 3.54 & 4.04 & 4.63 & 1.56 \\
\hline SD. & 963,63 & 1.11 & .84 & 1.04 & .90 & .70 & .75 & .68 & .91 & .85 & .86 & 1.43 & .58 \\
\hline
\end{tabular}

Note: $N=551$.

** $p<.01, * p<.05$. 
Table 2. Significant Indirect Paths of the Economic Stress Model in Emerging Adulthood, ESM-EA.

\begin{tabular}{lll}
\hline & Unstandardized & Standardized \\
& parameter & parameter \\
& estimates $(\mathrm{SE})$ & estimates (SE)
\end{tabular}

Indirect Paths to Life Satisfaction (28 yrs)

Income insufficiency $(25 \mathrm{yrs}) \rightarrow$ Economic pressure $\quad .07 *(.03) \quad .05 *(.03)$

$(25 \mathrm{yrs}) \rightarrow$ Financial capability $(28 \mathrm{yrs}) \rightarrow$ Life

satisfaction (28 yrs)

Economic pressure $(25 \mathrm{yrs}) \rightarrow$ Financial capability $(28 \quad-.14 *(.07) \quad-.07 *(.04)$

yrs $) \rightarrow$ Life satisfaction (28 yrs)

\section{Indirect Paths to Depressive symptoms (28 yrs)}

Income insufficiency $(25 \mathrm{yrs}) \rightarrow$ Economic pressure $\quad-.03 *(.01) \quad-.05 *(.03)$

$(25$ yrs $) \rightarrow$ Financial capability $(28$ yrs $) \rightarrow$ Depressive

symptoms (28 yrs)

Income insufficiency $(25 \mathrm{yrs}) \rightarrow$ Economic pressure $\quad-.08 *(.04) \quad-.14 *(.07)$

$(25 \mathrm{yrs}) \rightarrow$ Depressive symptoms $(28 \mathrm{yrs})$

Economic pressure $(25 \mathrm{yrs}) \rightarrow$ Financial capability $(28 \quad .06 *(.03) \quad .08 *(.03)$

yrs $) \rightarrow$ Depressive symptoms (28 yrs)

Note: ${ }^{*} p<.05$. Only the indirect paths of the revisited Economic Stress Model in Emerging Adulthood, ESM-EA are listed. For direct paths, see Figure 2. 


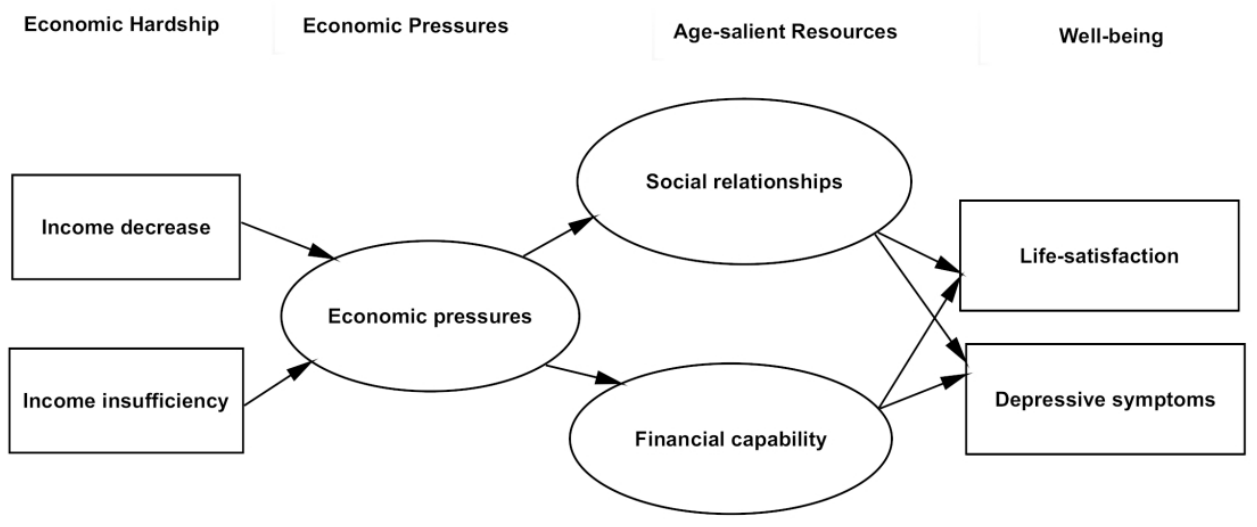

Conceptual three-wave Economic Stress Model in Emerging Adulthood (ESM-EA) from own economic hardship to well-being, mediated by economic pressures, social relationships and financial capability. The ovals represent latent constructs and the boxes manifest variables.

\section{$825 \times 583 \mathrm{~mm}(72 \times 72$ DPI $)$}




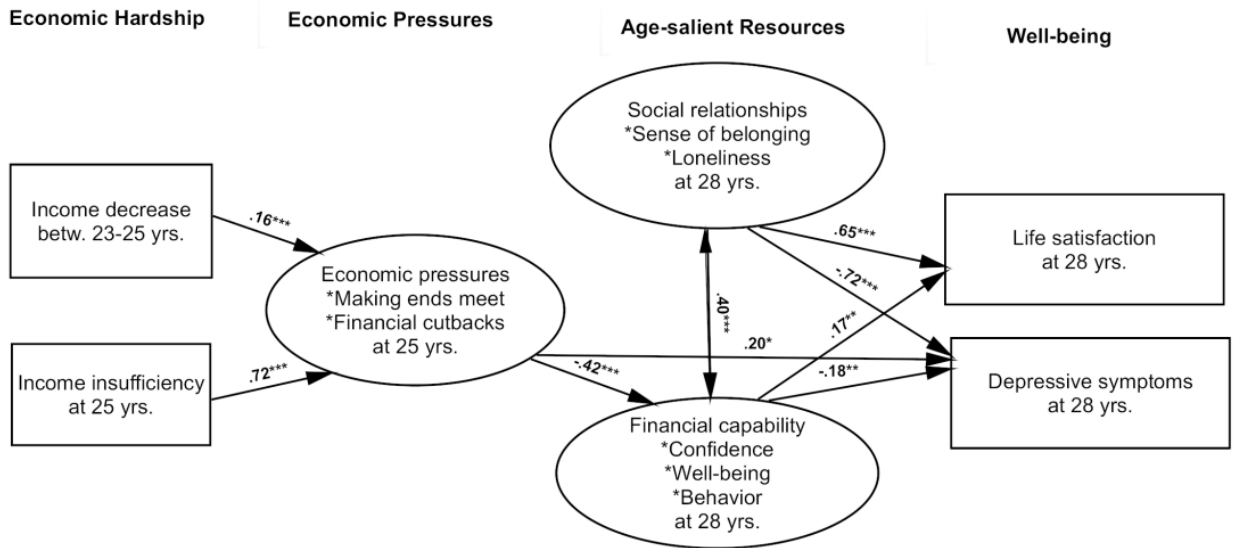

2011-2013

2013

2016

2016

Results of the direct paths between economic hardship and well-being. Non-significant paths are not shown. The ovals represent latent constructs and the boxes manifest variables. The residuals between the endogenous variables (income decrease and income insufficiency) were allowed to covariate, as well as between the outcome variables (life satisfaction and depressive symptoms) in order to reflect shared sources of variance not included in the model.

$825 \times 583 \mathrm{~mm}(72 \times 72 \mathrm{DPI})$ 
Supplemental online material

Distribution (\%) of Demographic Variables.

\begin{tabular}{|c|c|c|}
\hline & $\%$ & $\mathrm{~N}$ \\
\hline \multicolumn{3}{|l|}{ Gender } \\
\hline Female & 55.5 & 306 \\
\hline Male & 44.5 & 245 \\
\hline \multicolumn{3}{|l|}{ Mother's Socioeconomic Status } \\
\hline Entrepreneur (self-employed) & 1.4 & 7 \\
\hline Higher white-collar employee & 26.5 & 131 \\
\hline Lower white-collar employee & 52.5 & 260 \\
\hline Blue-collar worker & 13.7 & 68 \\
\hline Not in employment & 5.1 & 25 \\
\hline Other & .8 & 4 \\
\hline \multicolumn{3}{|l|}{ Father's Socioeconomic Status } \\
\hline Entrepreneur (self-employed) & 6.3 & 30 \\
\hline Higher white-collar employee & 33.8 & 160 \\
\hline
\end{tabular}




\begin{tabular}{lcc}
\hline Lower white-collar employee & 19.8 & 94 \\
Blue-collar worker & 34.6 & 164 \\
Not in employment & 5.3 & 25 \\
Other & .2 & 1 \\
Highest Educational Degree at Age 28 & & 239 \\
Upper secondary education: High school or vocational school degree & 43.8 & 139 \\
Polytechnic degree & 25.4 & 141 \\
University degree & 25.8 & 27 \\
Other & 4.9 & 162 \\
Education and Work Situation at Age 28 & & 371 \\
Studying at a university / polytechnic institute / other & 29.4 \\
Working & 67.3 & 56 \\
Unemployed & 10.2 & 5 \\
\hline
\end{tabular}


Supplemental online material

Loading Estimates of Manifest Variables for Latent Constructs of the SEM.

\begin{tabular}{lllll}
\hline & & & \\
\hline Manifest variables for latent constructs & $\begin{array}{l}\text { Unstandardized } \\
\text { parameter } \\
\text { estimates }\end{array}$ & SE & $\begin{array}{l}\text { Standardized } \\
\text { parameter } \\
\text { estimates }\end{array}$ & Critical ratios \\
\hline Economic pressures & & & .78 & 1.00 \\
Making ends meet & 1.20 & .05 & .76 & $15.45^{* * *}$ \\
Financial cutbacks & & & .35 & 1.00 \\
Social relationships & 1.58 & .04 & .59 & $13.94^{* * *}$ \\
Loneliness & 1.49 & .04 & .72 & $16.81^{* * *}$ \\
Sense of belonging: societal domain & 1.22 & .05 & .55 & $12.32^{* * *}$ \\
Sense of belonging: every day domain & & & & 1.00 \\
Sense of belonging: family domain & & & .75 & $29.34^{* * *}$ \\
Financial capability & 1.01 & .03 & .80 & $23.65^{* * *}$ \\
Financial confidence & 0.88 & .03 & .71 & \\
Financial well-being & & & & \\
Financial behavior & &
\end{tabular}

$$
\begin{aligned}
& \text { Note: } \mathrm{N}=546 \\
& * * * p<.001 .
\end{aligned}
$$

